\title{
Neoliberalism: From New Liberal Philosophy to Anti-Liberal Slogan
}

\author{
Taylor C. Boas • Jordan Gans-Morse
}

Published online: 21 February 2009

(C) The Author(s) 2009. This article is published with open access at Springerlink.com

\begin{abstract}
In recent years, neoliberalism has become an academic catchphrase. Yet, in contrast to other prominent social science concepts such as democracy, the meaning and proper usage of neoliberalism curiously have elicited little scholarly debate. Based on a content analysis of 148 journal articles published from 1990 to 2004, we document three potentially problematic aspects of neoliberalism's use: the term is often undefined; it is employed unevenly across ideological divides; and it is used to characterize an excessively broad variety of phenomena. To explain these characteristics, we trace the genesis and evolution of the term neoliberalism throughout several decades of political economy debates. We show that neoliberalism has undergone a striking transformation, from a positive label coined by the German Freiberg School to denote a moderate renovation of classical liberalism, to a normatively negative term associated with radical economic reforms in Pinochet's Chile. We then present an extension of W. B. Gallie's framework for analyzing essentially contested concepts to explain why the meaning of neoliberalism is so rarely debated, in contrast to other normatively and politically charged social science terms. We conclude by proposing several ways that the term can regain substantive meaning as a "new liberalism" and be transformed into a more useful analytic tool.
\end{abstract}

For helpful comments on earlier drafts, we are grateful to David Collier, Ruth Berins Collier, Stephen Collier, Miguel de Figueiredo, Thad Dunning, Danny Hidalgo, Maiah Jaskoski, Marcus Kurtz, Simeon Nichter, Shannon Stimson, Steven Vogel, Nicholas Ziegler, participants in the U.C. Berkeley Latin American Politics research seminar, and two anonymous reviewers. Both authors' work on this article was supported by National Science Foundation Graduate Research Fellowships.

T. C. Boas $(\bowtie) \cdot$ J. Gans-Morse

Department of Political Science, University of California, Berkeley, 210 Barrows, Berkeley,

CA 94720-1950, USA

e-mail: tboas@berkeley.edu

J. Gans-Morse

e-mail: g_morse@berkeley.edu 
Keywords Neoliberalism - Development · Political economy - Germany - Chile · Latin America $\cdot$ Pinochet $\cdot$ Gallie $\cdot$ Essentially contested concept $\cdot$ Concept analysis

\section{Introduction}

Neoliberalism has rapidly become an academic catchphrase. From only a handful of mentions in the 1980s, use of the term has exploded during the past two decades, appearing in nearly 1,000 academic articles annually between 2002 and 2005 . Neoliberalism is now a predominant concept in scholarly writing on development and political economy, far outpacing related terms such as monetarism, neoconservatism, the Washington Consensus, and even "market reform" (Fig. 1).

Despite its prevalence, scholars' use of the term neoliberalism presents a puzzle. Neoliberalism shares many attributes with "essentially contested" concepts such as democracy, whose multidimensional nature, strong normative connotations, and openness to modification over time tend to generate substantial debate over their meaning and proper application (Gallie 1956). In stark contrast to such concepts, the meaning of neoliberalism has attracted little scholarly attention. In a review of 148 articles on neoliberalism published in the top comparative politics, development, and Latin American studies journals between 1990 and 2004, we did not find a single article focused on the definition and usage of neoliberalism, nor are we aware of one published elsewhere.

In this article, we analyze contemporary scholars' unusual use of neoliberalism in the study of political economy and offer an explanation for why this situation has come about. Based on a content analysis of journal articles, the first section of the article documents three key characteristics of this use. First, neoliberalism is employed asymmetrically across ideological divides: it is used frequently by those who are critical of free markets, but rarely by those who view marketization more positively. In part, proponents avoid the term because neoliberalism has come to signify a radical form of market fundamentalism with which no one wants to be associated. Second, neoliberalism is often left undefined in empirical research, even

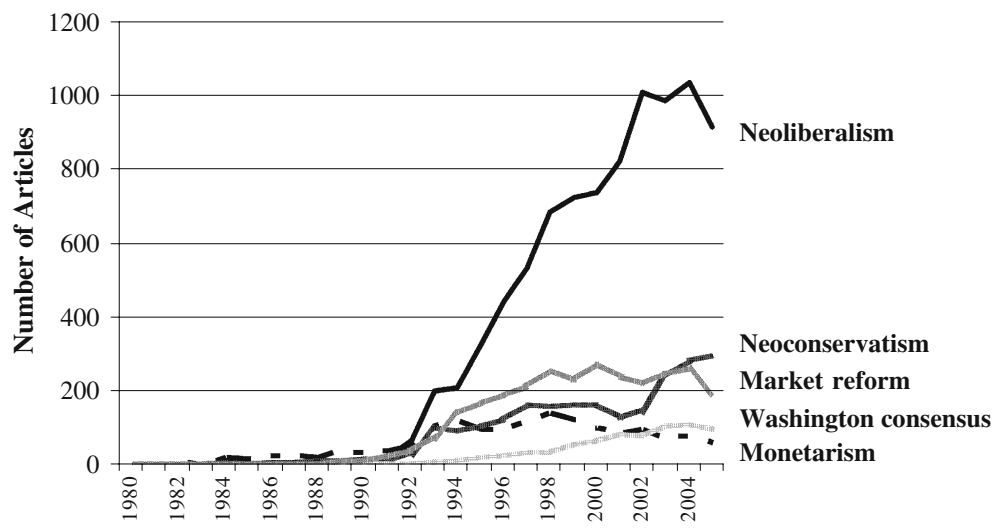

Fig. 1 Neoliberalism and related terms in academic journals, 1980-2005. Results are based on full-text searches of peer-reviewed, English-language academic journals in the Infotrac Expanded Academic ASAP database 
by those who employ it as a key independent or dependent variable. Third, the term is effectively used in many different ways, such that its appearance in any given article offers little clue as to what it actually means.

The contemporary use of neoliberalism is even more striking because scholars once employed the term nearly the opposite of how it is commonly used today. As we demonstrate in the second section, the term neoliberalism was first coined by the Freiberg School of German economists to denote a philosophy that was explicitly moderate in comparison to classical liberalism, both in its rejection of laissez-faire policies and its emphasis on humanistic values. These characteristics imbued neoliberalism with a common substantive meaning and a positive normative valence: it denoted a "new liberalism" that would improve upon its classical predecessor in specific ways. Only once the term had migrated to Latin America, and Chilean intellectuals starting using it to refer to radical economic reforms under the Pinochet dictatorship, did neoliberalism acquire negative normative connotations and cease to be used by market proponents.

We argue that the patterns of asymmetric use emerging out of this historical transformation contribute to current scholars' tendency to apply the term neoliberalism broadly, yet offer few precise definitions. In developing this explanation, the third section of the article expands upon Gallie's (1956) framework for analyzing essentially contested concepts, arguing that there are multiple levels of contestation. Scholars may contest not only the meaning and application of a concept, but also its normative valence and the term used to denote it. In the case of neoliberalism, the contested normative valence of the free market-related concepts to which the term refers, combined with terminological contestation over how to label these concepts, has led scholars with divergent normative assessments of the free market to adopt different terminology. When the use of language expresses only one side of a politically charged argument, choice of terminology takes the place of a direct confrontation of ideas, and meaningful debate suffers.

In the conclusion, we maintain that for neoliberalism to be of analytic rather than rhetorical value for social scientists, it must be imbued with substantive meaning as to what is new or distinct about this form of liberalism. We propose three ways that this term might be used more productively in future research: to explain how modern capitalism is fundamentally different from previous models of political economy; to characterize what is distinct about liberalism in developing versus advanced industrial countries; or to refine typologies of national market economies. While recognizing that a future consensus definition of neoliberalism must be the product of the type of debate that is currently lacking, we are hopeful that our effort can initiate the same sort of process that has transformed other politically charged terms like corporatism and totalitarianism into useful analytic tools.

\section{The Usage of Neoliberalism in Contemporary Social Science}

Many important social science concepts can be considered essentially contested concepts, whose strong normative character, multidimensional nature, and openness to modification over time provoke much debate over their meaning and proper application (Gallie 1956). For example, the concept of democracy has been the 
subject of substantial scholarly inquiry, leading to some consensus in favor of the "procedural minimum" definition (Collier and Levitsky 1997). Similarly, the increasing prevalence of the term neopopulism in the 1990s, particularly within the field of Latin American studies, was accompanied by extensive debate over the meaning of the "neo" qualifier and how new forms of populism should or should not be distinguished from older ones (Roberts 1995; Lynch 1999; Weyland 2001).

Neoliberalism shares many of the above-listed characteristics with essentially contested concepts such as democracy and populism, yet the manner in which it is used in contemporary scholarship differs in several important and potentially problematic ways. First, neoliberalism is used asymmetrically across ideological divides, rarely appearing in scholarship that makes positive assessments of the free market. Second, those who employ the term in empirical research often do not define it. And third, scholars tend to associate neoliberalism with multiple underlying concepts, including a set of policies, a development model, an ideology, and an academic paradigm.

In this section, we document these aspects of the usage of neoliberalism, drawing upon the results of a content analysis of 148 articles from the nine development, Latin American Studies, and comparative politics journals in which the term most frequently appears. ${ }^{1}$ In each journal, we analyzed all articles published between 1990 and 2004 that included the word "neoliberal" or any of its variants in the title or abstract. Table 1 lists the journals and number of articles from each; an “Appendix" explains our sampling and coding procedure. ${ }^{2}$

\section{Asymmetric Patterns of Use}

Despite the prevalence of the term neoliberalism, its application in contemporary scholarship is uneven. In the present-day study of political economy, the term neoliberalism is most frequently employed by those who are critical of the free market phenomena to which it refers.

Neoliberalism is not exclusively a bad word, but one rarely sees it used as a good word-as the term that an author chooses when emphasizing the positive aspects of a pro-market philosophy, development model, or reform policy. One compelling indicator of the term's negative connotation is that virtually no one self-identifies as a neoliberal, even though scholars frequently associate others-politicians, economic advisors, and even fellow academics - with this term. While a fifth of the articles on neoliberalism in our sample referred prominently to other people as neoliberals, in

\footnotetext{
${ }^{1}$ The absence of economics journals from the sample reflects the fact that economists rarely use the term. A full-text JSTOR search for English-language academic articles (excluding reviews and opinion pieces) in the journals JSTOR categorizes under each discipline found that from 1990-2004, neoliberalism appeared only 49 times in 52 economics journals ( 0.9 per journal), but 1,154 times in 89 political science, sociology, and geography journals (13 per journal). Our search excluded from the JSTOR economics category several journals that clearly represent the scholarship of other disciplines: Economic Geography, Annals of the American Academy of Political and Social Science, and Canadian Journal of Political Science.

2 The large number of articles from Third World Quarterly should not be interpreted as sampling error, since our selection of articles was purposive rather than random. Our sample simply reflects where scholars publish peer-reviewed research using the term neoliberalism. Nonetheless, we recalculated all of our descriptive statistics excluding this journal and found a noteworthy difference only with respect to the normative valence of articles using the term, as reported below.
} 
Table 1 Journals and articles analyzed

Third World Quarterly

Studies in Comparative International Development

World Development

Latin American Research Review

${ }^{\text {a }}$ Before 2001, entitled Journal of Interamerican Studies and World Affairs.

all of our research, we did not uncover a single contemporary instance in which an author used the term self-descriptively, and only one - an article by New York Times columnist Thomas Friedman (1999) - in which it was applied to the author's own policy recommendations.

Related to neoliberalism's negative normative valence is the fact that it often denotes a radical, far-reaching application of free-market economics unprecedented in speed, scope, or ambition. Kurt Weyland (2002: 13-14), for example, finds it necessary to distinguish neoliberal reform, defined as a process with "the radical goal of creating a free-market economy," from the more moderate term "market reform," denoting only a partial curtailment of state involvement in economic affairs. Those with sympathy toward the free market sometimes cite these radical connotations as their reason for avoiding the term neoliberalism. John Williamson (2003: 326), author of the phrase "Washington Consensus," has sought to differentiate his specific and delimited set of economic prescriptions from the more extreme notion of neoliberalism, which he considers "an ideological agenda valid for all time that was supposedly being imposed on all countries." Indeed, the alternative terms typically embraced by proponents of the free market - consensus, orthodoxy, adjustment, and stabilization - imply mainstreamness and a return to normalcy rather than radicalism.

In coding the normative valence of journal articles in our sample, we analyzed both normative statements about neoliberalism itself, and also the association of neoliberalism with other empirical phenomena that have clear normative implications. Polemical references such as "the IMF's neoliberal crusaders" and "bone-dry neoliberals such as...Milton Friedman of the Chicago School" are clear examples of negative usage (Bullard 1998: 505, 538). Arguing that neoliberalism has increased poverty or is only tenable under conditions of authoritarianism would also fall into the negative category. Emphasizing a case where neoliberal reform tamed hyperinflation or spurred dramatic growth would qualify as positive usage, whereas arguments that associate neoliberalism with empirical phenomena that are neither clearly good nor bad — such as a shift in a country's party system — can be considered instances of neutral use. In articles where more than one of these uses was equally predominant, we coded the normative valence as mixed. 
Table 2 The normative valence of neoliberalism

\begin{tabular}{lllll}
\hline & Positive & Negative & Neutral & Mixed \\
\hline Articles & $4(3 \%)$ & $66(45 \%)$ & $66(45 \%)$ & $12(8 \%)$ \\
\hline
\end{tabular}

Percentages do not sum to 100 because of rounding error.

The results of our content analysis of journal articles confirm that negative uses of neoliberalism vastly predominate over positive uses. We categorized an equal number of articles as neutral and negative (66 articles, or $45 \%$ ), but only $3 \%$ of the articles as positive, with an additional $8 \%$ as mixed (Table 2$){ }^{3}$

\section{Lack of Definition}

Scholars not only tend to attach a negative normative valence to neoliberalism; they also frequently fail to define the term when using it in empirical research. In our content analysis, we employed extremely permissive criteria for characterizing an article as defining neoliberalism. We counted not only explicit and self-conscious definitions such as "by neoliberalism I mean..." but also those that offered only implicit "definitions-in-passing," in which an author applied the neoliberal label to specific empirical phenomena without explaining why. ${ }^{4}$ Despite this permissive approach, we nonetheless found that a full $69 \%$ of articles offered no definition at all (Table 3). Nor has the situation improved over time. Between 1990 and 1997, approximately $63 \%$ of the articles failed to provide any definition; between 1998 and 2001, 69\% offered no definition; and from 2002-2004, 76\% left neoliberalism undefined. $^{5}$

The problem of neoliberalism remaining undefined in empirical research might be less serious if the offending studies tended to be those invoking neoliberalism as a background condition as opposed to a key independent or dependent variable. Studies using neoliberalism as a contextual variable were in fact less likely to define it, with $74 \%$ offering no definition. However, even among empirical articles where neoliberalism was an independent or dependent variable, $65 \%$ did not define the term.

The tendency to use the term neoliberalism in empirical research without defining it contrasts with the use of other important social science concepts. Examining how scholars employ democracy in empirical research, David Collier and Steven Levitsky $(1996: 4,7)$ found that "much of the usage by these authors is linked to explicit definitions," which are "often presented and applied with considerable care." The concept of democracy tends to encourage such good

\footnotetext{
${ }^{3}$ The high proportion of negative uses of neoliberalism in our overall sample partially reflects the preponderance of these articles in Third World Quarterly. When this journal was omitted, 27\% of the remaining articles assigned neoliberalism a negative normative valence, $57 \%$ were neutral, and $13 \%$ were mixed. These alternative results still underscore the asymmetric use of neoliberalism, since the proportion of those who use the term in a positive sense-3\%-remained unchanged. Regardless of the intensity of scholars' negative associations for neoliberalism, it is rarely used as a positive term.

${ }^{4}$ These two types of definitions were about equally prevalent.

${ }^{5}$ These three time periods roughly divide our sample of 148 articles into thirds.
} 
Table 3 Articles defining neoliberalism

\begin{tabular}{lcc}
\hline & Defined & Undefined \\
\hline Entire Sample & $46(31 \%)$ & $102(69 \%)$ \\
$\mathbf{1 9 9 0 - 1 9 9 7}$ & $18(37.5 \%)$ & $30(62.5 \%)$ \\
$\mathbf{1 9 9 8 - 2 0 0 1}$ & $17(31 \%)$ & $38(69 \%)$ \\
$\mathbf{2 0 0 2 - 2 0 0 4}$ & $11(24 \%)$ & $34(76 \%)$ \\
Neoliberalism as IV or DV & $32(35 \%)$ & $60(65 \%)$ \\
Neoliberalism as context & $8(26 \%)$ & $23(74 \%)$ \\
\hline
\end{tabular}

scholarly habits in part because of the lively debate over alternative definitions, obligating scholars to clearly specify which of the potential meanings they have in mind. If there were a scholarly consensus regarding the meaning of neoliberalism, the lack of explicit definitions might not be so problematic. However, as discussed below, scholars' use of the term does not evidence any such agreement as to what it actually means.

\section{The Many Types of Neoliberal Phenomena}

Those who use the term neoliberalism find many occasions to do so, applying it to a wide range of economic, social, and political phenomena. We argue that there are at least four distinct and potentially overlapping ways how neoliberalism is used in the study of political economy: to denote a set of economic reform policies, a development model, a normative ideology, and an academic paradigm. ${ }^{6}$ In our content analysis of journal articles, we coded whether the author employed neoliberalism in each of these different ways (Table 4). ${ }^{7}$

The most common use of neoliberalism refers to economic reform policies. Scholars typically characterize three sets of polices as being neoliberal: those that liberalize the economy, by eliminating price controls, deregulating capital markets, and lowering trade barriers; those that reduce the role of the state in the economy, most notably via privatization of state-owned enterprises; and those that contribute to fiscal austerity and macroeconomic stabilization, including tight control of the money supply, elimination of budget deficits, and curtailment of government subsidies (e.g., Wilson 1994: 165; Aminzade 2003: 48). We characterized the use of neoliberalism as falling into the "policy" category when authors consistently associated the term with one or more of these specific policies.

\footnotetext{
${ }^{6}$ Neoliberalism is also commonly used to refer to an era, as well as specific groups of people. Both of these categories can typically be subsumed beneath one or more of the others, since "a neoliberal" is someone who advocates neoliberal policies, expounds a neoliberal ideology, etc., and a neoliberal era is one in which neoliberalism (however defined) is hegemonic. Beyond the field of political economy, "neoliberal" also refers to a theoretical paradigm in international relations and was sometimes used as a 1980 s term for centrist Democrats.

${ }^{7}$ In coding this variable, we sought to identify the areas of use that predominated in the article rather than those that constituted off-hand mentions. We also avoided letting the author's choice of language determine our coding. For instance, when scholars refer to a "neoliberal paradigm," they are often talking about a development model rather than an academic paradigm.
} 
Table 4 The broad uses of neoliberalism

\begin{tabular}{lcccc}
\hline & Policies & Development Model & Ideology & Paradigm \\
\hline Articles & $106(72 \%)$ & $58(39 \%)$ & $32(22 \%)$ & $20(14 \%)$ \\
\hline
\end{tabular}

These categories are not mutually exclusive, hence percentages do not sum to 100 .

A second use of neoliberalism refers to a development model. A neoliberal model is a comprehensive development strategy with economic, social, and political implications. Rather than merely a technocratic list of solutions for economic ills, a model involves a set of economic theories linking disparate policies together into a coherent recipe for growth or modernization; prescriptions for the proper role of key actors such as labor unions, private enterprise, and the state; and an explicitly political project to carry out these prescriptions and ensure that actors play by the rules of the game. In this sense, the neoliberal model can be contrasted with its predecessor, the state-led development model, which implied very different political roles for labor, capital, and the state. Thus, many scholars maintain that the implementation of a neoliberal model involves a restructuring of state-society relations (e.g., Kurtz 1999: 414; Riethof 1999: 1050).

A third way that neoliberalism is used is to denote an ideology. When speaking of a neoliberal ideology, scholars refer to normative ideas about the proper role of individuals versus collectivities and a particular conception of freedom as an overarching social value. David Carruthers (2001: 345), for instance, argues that "neoliberal ideology seeks to restrict the state to a minimum and to maximise the scope of individual freedom.... Political leaders should not impose any single utopia; rather, individuals should be free to pursue their own, mediated by exchange relationships in the marketplace." If a neoliberal development model is a specific plan for how a certain society will be organized, a neoliberal ideology is a more general statement about how society should be organized.

A final use of the term neoliberalism is to characterize an academic paradigm. Unlike a normative ideology, a neoliberal paradigm consists of positive assumptions about how markets operate; in this sense, it is often seen as closely related to neoclassical economic theory. John Brohman (1995: 136), for instance, argues that in the neoliberal approach, "the behaviour of individuals is predetermined by a set of universal rational rules that are deductively posited. Private producers and consumers are presupposed to be utility and profit maximisers who respond rationally and efficiently to correct market signals." Some scholars also use the notion of a neoliberal paradigm in the context of more specific academic debates. Lawrence King (2002: 407) uses neoliberalism to refer not only to a policy package, but also to a framework for studying and evaluating countries' transitions from socialism to capitalism.

In sum, the use of neoliberalism in the contemporary study of political economy differs from that of other normatively charged social science concepts in three potentially problematic ways. First, its negative normative valence and connotations of radicalism have produced asymmetric patterns of use across ideological divides. Second, scholars who do use the term neoliberalism tend not to define it in empirical research, even when it is an important independent or dependent variable. And third, 
the term is applied to multiple distinct phenomena, from a set of economic policies or development model to an ideology or academic paradigm. In present usage, neoliberalism conveys little common substantive meaning but serves as a clear indicator that one does not evaluate free markets positively.

\section{The Historical Evolution of Neoliberalism: Explaining its Present-Day Characteristics}

From its origins in interwar Germany to its contemporary usage by social scientists, the term neoliberalism has undergone a remarkable transformation. While today's scholars frequently use neoliberalism to refer to negative, radical phenomena, the economic philosophers of the German Freiberg School used the term in a positive and self-identifying sense and considered neoliberalism to be a moderate alternative to classical liberalism. In contrast to the current tendency to use neoliberalism in many ways without defining it, the original German neoliberals devoted extensive attention to the term's meaning and applied it specifically to their economic philosophy. When neoliberalism made its academic debut, the term truly denoted a new form of liberalism, and even those who were critical of the philosophy it represented used it descriptively rather than pejoratively. In other words, neoliberalism was originally used nearly the opposite of how it is today.

What accounts for this historical shift in the usage of neoliberalism? In this section, we trace the evolution of the term from its European roots to its adoption and then modification in Latin America between the 1960s and 1980s. We then analyze the role of the Chilean economic reforms of the 1970s in shaping contemporary scholars' perceptions of neoliberalism.

Neoliberalism of the German Freiberg School: A Moderate Alternative to Classical Liberalism

The term neoliberalism first appeared in scholarly writings on political economy in the period between the two world wars. The instability of the interwar years, plagued by inflation and depression that bred radical ideologies and unleashed devastation on Europe, convinced many intellectuals and politicians that capitalism was untenable. Yet pockets of liberals remained, including a small circle of economists and legal scholars associated with the German Freiburg School. These "new" liberals sought to resuscitate the liberal creed by offering a fundamental overhaul of classical liberalism. As such, they propounded a notion of neoliberalism (also referred to as ordoliberalism) quite different from the connotations the term carries in present-day scholarly discourse. ${ }^{8}$

\footnotetext{
${ }^{8}$ The concept of "ordo," the Latin word for order, figured prominently in the Freiburg School's work. Ordo referred to an ideal economic system that would be more orderly than the laissez-faire economy advocated by classical liberals (Oliver 1960: 133-134). Many scholars used ordoliberalism and neoliberalism interchangeably when referring to the Freiberg School, though some Freiberg economists themselves preferred ordoliberalism (Gerber 1994: 31).
} 
Whereas contemporary scholars often equate neoliberalism with market fundamentalism, the Freiburg School's faith in the free market was moderate and pragmatic when compared to that of nineteenth-century liberals. First, Freiberg School economists argued that for the free market to function, the state must play an active role. The German neoliberals accepted the classical liberal notion that competition among free individuals drives economic prosperity, but they argued that powerful private actors - the monopolies and cartels that decimated Germany's small businesses in the interwar years - could pose a threat to freedom of competition. To keep private interests in check, the neoliberals supported the creation of a welldeveloped legal system and capable regulatory apparatus that went well beyond the minimalist, night-watchman state promoted by followers of Adam Smith (Megay 1970: 424-425; Gerber 1994: 36-37). Alexander Rüstow, a prominent German neoliberal, summarized this position in a 1932 essay entitled "Free EconomyStrong State" (Friedrich 1955: 512). In other words, the neoliberals sought to divorce liberalism - the freedom of individuals to compete in the marketplacefrom laissez-faire - freedom from state intervention. They argued that a laissez-faire state policy stifles competition as the strong devour the weak (Oliver 1960: 118; Boarman 1964: 25; Gerber 1994: 33).

A second element of German neoliberals' moderate stance was their willingness to place humanistic and social values on par with economic efficiency. Alfred Müller-Armack coined the phrase "social market economy" in the 1940s to emphasize the egalitarian and humanistic bent of this new form of liberalism (Boarman 1964: 21; Gerber 1994: 60). Walter Eucken, one of the founders of the Freiburg School, claimed in 1952 that "social security and social justice are the greatest concerns of our time" (Gerber 1994: 37). Another prominent neoliberal during this period, Wilhelm Röpke, criticized classical liberalism as "blind to the deep-seated intellectual and social evils of our...civilization" (Megay 1970: 427). The German neoliberals' concern that the rules of the game not favor the powerful and wealthy also led some of them to favor limited income redistribution (Gerber 1994: 38). While still opposed to full-scale Keynesian employment policies or an extensive welfare state, the German neoliberals held views on social policy "that would have shocked the Manchesterians" (Boarman 1964: 27). To be sure, this support for welfare policies was not purely altruistic; the neoliberals were seeking to restore social order following the chaos of the preceding decades. Nevertheless, their vision of a social market economy clearly sets them apart from the market fundamentalism often associated with neoliberalism today.

In contrast to the negative connotations and asymmetric use of neoliberalism in contemporary social science, the "neo" qualifier of German neoliberalism was intended to convey a positive notion of renovation, and multiple groups of scholars sought to lay claim to the term. While no contemporary scholar self-identifies as neoliberal, the Freiberg economists not only used the term to describe themselves and their philosophy, but also debated whose liberal theories truly deserved the "neo" label. Supporters of a more traditional form of liberalism, such as Austrian economist Ludwig von Mises, were "referred to by the neo-liberals as "palaeoliberals" for clinging to an outdated faith in unfettered markets (Friedrich 1955: $512 \mathrm{n}$ ). Other liberal economists with fundamentally different ideas sought to appropriate the desirable neoliberal label, though members of the Freiberg School 
resisted these efforts. Rüstow complained in 1960 that "contemporary representatives of paleoliberalism call themselves neoliberal, although our neoliberalism arose precisely in contrast to...paleoliberalism" (Megay 1970: 427).

Finally, in contrast to the diverse ways that neoliberalism is used in present-day scholarship, the Freiberg School primarily assigned the term to a normative ideology, with specific claims about how society should be organized around conceptions of liberty and humanistic values (Hanslowe 1960: 96). As Reinhard Behlke wrote in 1961, "neoliberalism is not to be viewed as a direction in economics or economic policy, but as a humanistically based intellectual orientation" (Gerber 1994: 36n). This neoliberal ideology was hardly confined to the ivory tower; Freiberg School economists occupied key positions in the post-war government, and their ideas were influential in German economic policy (Gerber 1994: 58-59). Ludwig Erhard, the economics minister who presided over the two post-war decades of economic growth that came to be known as the "German miracle," identified with the neoliberals and implemented many of their prescriptions (Friedrich 1955: 510; Oliver 1960: 119; Boarman 1964: 24; Gerber 1994: 61). Nonetheless, Erhard referred to his overall development model as a social market economy, with the term neoliberalism reserved for the philosophy that inspired it.

While present-day scholarship often identifies Friedrich Hayek and Milton Friedman as the fathers of neoliberalism, most scholars of the period understood the term as referring to the German experience and its principal economic theorists. In academic articles and book reviews published in the 1950s and 1960s, neoliberalism was most often associated with Germany or specifically with the Freiberg School and such economists as Eucken, Röpke, Rüstow, and MüllerArmack. ${ }^{9}$ The earliest reference we found to neoliberalism as an economic philosophy was also specific to the German experience (Burns 1930: 490). Although Hayek enjoyed important intellectual ties to the neoliberals, serving as an editorial board member and frequent contributor to their journal Ordo, he much more vigorously opposed state intervention in the economy, even with respect to antimonopoly legislation (Friedrich 1955: 512; Hanslowe 1960; Oliver 1960: 119; Megay 1970; Gerber 1994: 32). Given his more fundamentalist stance, Hayek's name was only occasionally mentioned in conjunction with neoliberalism during this period, and Friedman's essentially never appeared.

Early Latin American References to Neoliberalism: Admiration for the German Model

In the 1960s, groups of Latin American (particularly Chilean) pro-market intellectuals began to notice the ideas of the Freiberg School and their implementation in post-war Germany. These intellectuals often used the Spanish term neoliberalismo - a direct translation of the German neoliberalismus - to refer to this school of thought. Promarket intellectuals in Latin America were particularly impressed by Erhard's "German miracle" and speculated about the possibility of accomplishing similarly

\footnotetext{
${ }^{9}$ These claims are based on a JSTOR search for variants of the term "neoliberal" in the full text of all indexed journal articles up to 1970 . Search results are available upon request.
} 
rapid growth and effective inflation control in their own countries. Given this close intellectual connection to the German experience, neoliberalism in 1960s Latin America meant essentially the same thing as it had for the Freiberg School-a philosophy that was more moderate than classical liberalism and favored using state policy to temper social inequality and counter a tendency toward monopoly.

To assess early Latin American use of the term neoliberalism, we examined the Chilean magazine PEC, a weekly published from 1963 to 1973, which is considered one of the main outlets for right-wing economic ideas in pre-Pinochet Chile (Valdés 1995; Pollack 1999). ${ }^{10}$ Although the relatively new term neoliberalism was not used extensively in $P E C$, the instances of its use were always consistent with the original German formulation, often referring specifically to the German miracle and the policies of Ludwig Erhard. The earliest appearance of the term was in an essay by Freiberg economist Wilhelm Röpke (1964) on the foundations of neoliberal thought. Soon after, the term was embraced by Latin Americans such as Enrique Chirinos Soto (1964), who criticized the Jorge Alessandri government's failure to tame inflation in Chile and argued that Alessandri "should have implemented a neoliberal economic policy identical to that of Erhard in Germany."

Usage of neoliberalism in PEC was also consistent with its original German meaning in that it emphasized humanistic values, a preoccupation with social welfare, and moderation vis-à-vis classical liberalism. As Santiago Labarca (1965: 12) says of Chilean politician Manuel Rivas Vicuña:

He was a liberal, but not a 19th-century liberal; rather, he was... a 'neoliberal.' He placed the idea of freedom above all other values. Nonetheless, that freedom was only unlimited in the ideological realm, while in the economic realm it should be bounded by solidarity with all mankind.... [H] e concerned himself with preventing man's exploitation of man, which had been the outcome of the old laissez-faire, laissez-passer liberalism. Thus, his enthusiastic work on the foundations of social legislation and his membership on the Labor Legislation Commission.

While neoliberalism was used primarily by pro-market scholars in Latin America in the 1960s, we found no evidence that critics of the free market sought to distance themselves from the term or employ other language. Marxist scholar Hernando Aguirre (1962), for instance, invokes neoliberalism similarly to that of the right-wing intellectuals publishing in PEC. While critical of the content of neoliberal thought, he does not use the term pejoratively, he accurately characterizes neoliberalism's claims about when the state should intervene in the economy, and he identifies neoliberalism with Erhard's "German miracle" and the theories of Röpke.

The Term Neoliberalism in the 1980s: Critiquing Market Fundamentalism

Two decades after it was first used by pro-market intellectuals in the 1960s, the term neoliberalism had come into much more prevalent use in Latin America. The way

\footnotetext{
${ }^{10}$ We examined this collection on microfilm in Chile's National Library, conducting a visual search for variants of the term "neoliberal" in all articles judged to relate to economic policy or philosophy. This process was obviously subject to human error, and we may have failed to find every instance of the term's use.
} 
that neoliberalism was most commonly employed in the 1980s was quite different from what neoliberalism had originally meant for Latin American scholars or the German Freiberg School. The first patterns of asymmetric use had begun to appear: critics of market reform used neoliberalism more often than proponents, who were already showing a preference for alternative terminology. Moreover, those who regularly used the term neoliberalism in the 1980s typically applied it in its presentday, radical sense, denoting market fundamentalism or a system that sought revolutionary changes in the relationship between state and society.

To assess how neoliberalism was used in Chile in the 1980s, we examined all instances of its appearance in the journal Estudios Públicos between 1980 and 1990. ${ }^{11}$ Pro-market scholars did not invoke neoliberalism frequently during this period - of the 18 articles in which the term was employed, only six made an unambiguously positive assessment of free markets (Fontaine 1980, Peña Vial 1985; Gallo 1986; Medina and Arreóla 1986; Valdés 1989; Irarrázaval 1990). These mentions were largely historical references to the Freiberg or Austrian schools; promarket authors avoided applying the neoliberal label to their own philosophy or the economic changes implemented in Chile and other countries of the Southern Cone. Most usage of neoliberalism came from scholars critical of the economic reforms under Pinochet, even though such scholars published only sporadically in the journal overall. These scholars used neoliberalism not only in reference to an economic philosophy, but also to characterize the economic system put in place in Chile after 1973, as well as its Chilean proponents (García 1983; Flisfisch 1984; Tironi 1985; Boeninger 1986; Berger et al. 1990).

Asymmetric use of neoliberalism was also evidenced by the language that critics and proponents of the free market used when engaging each other in debate. Particularly revealing are three transcripts of roundtable discussions with participation by academics of the right and of the center-left (Flisfisch and Fontaine 1983; Echeverría et al. 1985; Berger et al. 1990). In each instance, only free market critics used the term; pro-market scholars always employed other language, such as using the phrase "contemporary liberal authors" to refer to economic theorists that a critical scholar had labeled "neoliberals" (Echeverría et al. 1985). Similar preferences for the term neoliberalism can be found among free market critics on the nationalist right (e.g. Góngora 1986: 301).

By the 1980s, neoliberalism in Latin America had not only become a term with negative connotations employed principally by critics of market reform; it also had shifted in meaning from a more moderate to a radical or fundamentalist form of liberalism. Alejandro Foxley (1982: 149), for instance, argued that "the final objective of neoliberalism in Latin America is nothing less than radically transforming the way the economy operates and, in its most extreme version, the way society and political institutions are organized." Perhaps most significant, some pro-market scholars in Latin America began to accept neoliberalism's radical connotations and to reconceptualize "liberalism"-which previously referred to

\footnotetext{
${ }^{11}$ Estudios Públicos is the journal of the free market-oriented Centro de Estudios Públicos, one of Chile's most prominent think tanks. We downloaded the articles from www.cepchile.cl and did full-text searches for variants of the term neoliberalism.
} 
nineteenth-century "raw savage capitalism" — as something more moderate. Miguel Sang Ben and Andrés Van der Horst (1992: 368) argue:

We liberals should understand the inner-workings of society and economy so as to differentiate ourselves from the reductionist neoliberals with whom we are often confused.... Neoliberalism reduces solutions to the social crisis to marketbased economic recipes, even absent the ideal social conditions for the implementation of this market. The neoliberals should be labeled antiliberal because they prefer to sacrifice social welfare in the name of their "economyfirst" proposals.

Latin American scholarship in the 1980s had not only moved quite far from the notion of neoliberalism originally formulated by the Freiberg School, it had also ceased to identify the Germans as neoliberalism's intellectual progenitors. Rather, scholars writing during this period tended to associated neoliberalism with the theories of Hayek and, above all, Friedman (Echeverría et al. 1985; Góngora 1986; Ramos 1986), even though neither economist used the term to refer to himself. ${ }^{12}$

\section{Explaining the Terminological Shift: Scholarly Response to Pinochet's Radical Reforms}

What explains the change in usage of neoliberalism between the 1960s and the 1980s? We argue that the shift from a positive term implying moderation to a negative term connoting radicalism resulted from neoliberalism's association with the economic reforms in Augusto Pinochet's Chile and other countries of the Southern Cone in the 1970s. Indeed, Pinochet's 1973 coup emerges as something of a watershed in usage of neoliberalism. The earliest studies of Latin American political economy using neoliberalism in its negative, radical sense appeared just after this date (Chossudovsky 1975; Irisity 1975), while the most complete Spanishlanguage overview of German neoliberalism was published immediately before that (Ruiz 1972). Clearly, something occurred in this period to shift the meaning that Latin American scholars attached to neoliberalism, and Pinochet's coup and subsequent economic and political reforms constitute a strong candidate.

Though the economic philosophy of the Freiberg School found a positive reception among pro-market scholars in 1960s Latin America, the influence of these ideas in Chile was increasingly overshadowed by the more fundamentalist philosophy of Friedman and Hayek. In 1955, the University of Chicago launched a program in which a select group of Chilean students was invited to Chicago to pursue postgraduate studies in economics. These "Chicago Boys" worked directly under Friedman and his disciple Arnold Harberger, while also being exposed to Hayek, a professor at Chicago's Committee on Social Thought during this period. Returning to Chile in the 1960s, the newly minted economists began a concerted

\footnotetext{
${ }^{12}$ In a 1981 interview during a visit to Chile, Hayek stated unequivocally that he was a not a neoliberal and that he was willing to improve upon, but not fundamentally change, the postulates of classical liberalism (El Mercurio April 18, 1981). While Friedman (1951) embraced the neoliberal label and philosophy in one of his earliest political writings, he subsequently distanced himself from the term, trumpeting "old-style liberalism" in later manifestoes (Friedman 1955).
} 
effort to spread the philosophy and policy recommendations of the Chicago and Austrian schools, setting up think tanks and publishing in ideologically sympathetic media (Valdés 1995; Silva 1996; Pollack 1999). The economic philosophy of Friedman, Hayek, and their followers did not yet go by the name neoliberalism, but it was one of the dominant orientations among Chilean right-wing intellectuals by the time of the 1973 coup.

Though the first several years of Pinochet's military government were characterized by an ambiguous economic policy stance, the Chicago Boys eventually emerged as the primary architects of a reform program that sought a truly radical transformation of Chilean economy and society (Valdés 1995; Silva 1996; Kurtz 1999; Pollack 1999). Beginning with measures introduced in April 1975 , the latter half of the 1970 s witnessed rapid and extensive privatization, deregulation, and reductions in trade barriers. Eduardo Silva (1996: 97) explicitly justifies his use of the "radical" label for Chile's reforms:

First, the draconian nature of the stabilization measures and the speed and thoroughness of the market liberalization were without parallel in the recent history of Chile or Latin America. Second, the policies were intended to set in motion a sweeping transformation of the Chilean economy. Neoliberalism in Chile was also radical in its insensitivity to adversely affected economic sectors, including many capitalists and landowners.

Not only did Pinochet's reforms seek a "sweeping transformation of the Chilean economy," but they also sought to fundamentally alter the nature of social and political organization in Chile. In late 1978, when free-marketer José Piñera took over the Labor Ministry, state corporatist mechanisms were abandoned in favor of the "seven modernizations," policies that would reduce the role of the state and infuse competition and individualism into areas such as labor relations, pensions, health, and education (Pollack 1999). The seven modernizations were not merely policy reform; they constituted an attempt at fundamentally restructuring Chilean politics and society by undermining the basis for collective organization, mobilization, and demand making. This effort, in the words of Piñera himself, to "create the basis of a new political, economic, and social reality" (Kurtz 1999: 415) is what made Pinochet's reforms a truly revolutionary project.

During the height of military rule in Chile, neoliberalism acquired a new meaning as opposition scholars began using it to describe a set of political and economic reforms quite distinct from those advocated by the Freiberg School. According to Oscar Muñoz, one of the first opposition economists to use the term in academic writing, Chilean scholars' use of neoliberism was not a specific reference to the German neoliberals or any other theoretical revision of liberalism. Rather, it described the new "market fundamentalism" being implemented in Chile-one which differed from classical liberalism because it dispensed with political liberty, which classical liberalism (as well as the philosophy of Hayek) had always seen as inseparable from economic freedom. ${ }^{13}$ Characterizing Pinochet's project as neoliberal did not imply cognitive dissonance. Moreover, Muñoz notes that in the

${ }^{13}$ E-mail communication, December 19, 2006. 
polarized political climate of the 1970s, opposition scholars intentionally imbued the term with pejorative connotations, and using it constituted a "fairly open and blunt criticism" of the government's radical reforms.

It is important to recognize - but not overstate - the similar structural conditions that inspired both the philosophy of the Freiberg School and the policies of the Pinochet regime. The Germans sought to revise classical liberalism to "save the market" from the rising threat of socialism, whereas Pinochet and the Chicago Boys similarly sought to prevent any possible recurrence of a socialist experiment like that of Salvador Allende. However, key differences between these episodes explain the different connotations that neoliberalism acquired. Pinochet's policies were inspired by the more fundamentalist theories of Friedman and Hayek. They also responded to a real rather than potential shift toward socialism, and a much more polarized ideological climate. In addition, it was critics and not proponents of the free market who attached the neoliberal label to a new set of economic policies in Chile. Given their opposition to these reforms and the dictatorial conditions under which they were implemented, it is easy to understand how neoliberalism became a normatively negative term.

Opposition scholars' use of neoliberalism to denounce Pinochet's economic policies does not necessarily explain why the Chilean pro-market right chose to abandon instead of defend the term. One possibility is that the Chicago Boys still thought of neoliberalism as referring to the Freiberg School and wanted to emphasize the distinct origins of their own ideas. Yet propaganda concerns are an even more likely explanation. The military government's preferred term for its own economic model was a "social market economy" (Ffrench-Davis 1983: 163n)—a phrase that was closely associated with neoliberalism in Erhard's Germany, but never acquired the same negative connotations. For a government seeking to suggest that far-reaching economic reforms would not have deleterious social consequences, a term that prominently featured the word "social" was undoubtedly preferable to the more obscure "neoliberalism." Abandoning neoliberalism to its critics, while embracing the notion of a social market economy, may well have been an obvious choice.

Once established as a common term among Spanish-speaking scholars, neoliberalism diffused directly into the English-language study of political economy, such that its present-day usage is heir to the critical Latin American scholarship of the 1970s and 1980s. In one very important way, contemporary usage of neoliberalism has changed fundamentally since that period: it no longer denotes a new form of liberalism with specific features and empirical referents, but has become a vague term that can mean virtually anything as long as it refers to normatively negative phenomena associated with free markets. As the term neoliberalism has diffused broadly, nothing has prevented its meaning from drifting even more broadly. Why have scholars allowed this process to occur, rather than preserving neoliberalism as a term that should be applied more narrowly to the authoritarian free-market experiences of the Southern Cone? We turn to this question in the following section.

\section{Why the Meaning of Neoliberalism is not Subject to Debate}

The historical argument advanced thus far explains how neoliberalism acquired connotations of negativity and radicalism, but it cannot account for the scarcity of 
definitions in contemporary empirical research or the proliferation of multiple distinct uses. Indeed, the lack of debate over the definition of neoliberalism is particularly curious because normatively charged concepts in the social sciences often incur the opposite reaction: they become essentially contested concepts, generating extensive debate over their meaning and proper application. Why has neoliberalism, which clearly arouses scholars' passions, failed to do the same?

To address this question, we expand upon Gallie's (1956) framework for analyzing essentially contestable concepts. This approach allows us to explain characteristics of the scholarly use of neoliberalism - the tendency to offer multiple definitions, and the failure to debate the term's meaning - that cannot be accounted for through historical analysis. It also provides the opportunity to systematically compare neoliberalism with other terms such as democracy and fascism, whose usage differs in several crucial ways. Likewise, we offer a key extension to Gallie's theory itself, contributing to the ongoing scholarly effort to refine and improve upon this frequently invoked analytic framework (Freeden 1996; Collier et al. 2006).

We argue that, in contrast to Gallie's original formulation, there are actually multiple levels of contestation - distinct ways scholars can disagree with each other in their use of a particular concept. The case of neoliberalism illustrates a previously unrecognized type, which we call terminological contestation. When referring to free market policies, ideologies, or paradigms, contemporary scholars who are critical of these concepts use neoliberalism, while those who evaluate them favorably employ other language. This situation undercuts incentives to specify the meaning and proper application of neoliberalism, such that scholars use the term in multiple distinct ways without offering explicit definitions.

According to Gallie's framework, neoliberalism fulfills four necessary conditions for being an essentially contested concept. ${ }^{14}$ First, a concept of this sort "must be appraisive in the sense that it signifies or accredits some kind of valued achievement." The asymmetric use of neoliberalism in present-day scholarship clearly shows that it is value-laden, albeit with a negative normative valence. Second and third, an essentially contested concept must be internally complex, with multiple distinct definitional components, and variously describable, such that different weightings or orderings of these components produce different meanings. The diverse uses of neoliberalism in contemporary research show that it fulfills both conditions. Finally, an essentially contested concept must be open, its meaning subject to modification in response to changing historical circumstances. In the case of neoliberalism, the experience of Pinochet's economic reforms in Chile brought about just such a modification in meaning over time.

For most concepts that fulfill these necessary conditions for essential contestability, a process of intense debate tends to result, as users argue that their own particular definition of the concept constitutes its "one true meaning." It is logical that this process should encourage the formulation of explicit definitions, as scholars seek to

\footnotetext{
${ }^{14}$ Gallie (1956: 171-180) lists seven conditions, but only the first four are considered necessary (albeit jointly insufficient) for a concept to be contestable (Freeden 1996: 55). Condition five simply restates the definition of contestedness - that scholars aggressively debate the concept's meaning - and conditions six and seven describe additional characteristics of this scholarly debate. Here, we focus on the four criteria that could generate such debate and then go on to explain why it does not occur.
} 
defend the superiority of their preferred usage and differentiate it from alternatives. In the case of democracy, scholarly contestation has led to "precising the definition"adopting additional criteria to weed out cases that would qualify as democratic under alternative definitions, but do not seem to the analyst in question to be truly democratic (Sartori 1984; Collier and Levitsky 1997). Concepts with a negative normative valence, such as fascism, rape, and genocide, have seen similarly explicit contestation, though not necessarily with the same convergence on a common definition (Allardyce 1979; Reitan 2001; Straus 2001).

To understand why neoliberalism is essentially contestable according to Gallie's four criteria, yet ultimately remains uncontested, one must first acknowledge that the process of contestation is more complex than presented in Gallie's original framework. We argue that there are actually multiple levels of contestation at which debate over a particular concept can occur. Two of these levels concern the wellestablished distinction between a concept's intension, or general meaning, and its extension, or range of cases to which it applies (Sartori 1970: 1040-1046; Collier and Mahon 1993: 846; Freeden 1996: 56-57; Gerring 2001: 39-41). A third level concerns a concept's normative valence, or the range of "speech-acts," such as denunciation or praise, that the word can be used to perform (Skinner 1988). Marxism, for instance, is a concept with strong normative implications, yet unlike democracy or fascism, its valence is contested. For those who believe in free markets, it evokes a negative association; for Marxists and like-minded critics of capitalism, it is a positively valued label.

We argue that the example of neoliberalism underscores a fourth, previously unrecognized level at which a concept may be contested: the term used to refer to it. The concepts analysis literature routinely glosses over the distinction between a concept - an abstract idea or mental image used to organize analysis of empirical phenomena - and the term used to denote that concept (Skinner 1988: 119-121; Gerring 2001: 39-41; Seawright and Collier 2004: 279). The reason for this omission is most likely that the majority of important social science concepts, including those with strong normative connotations such as democracy, fascism, and Marxism, are associated with single standardized terms (see Table 5).

In contrast to the examples of democracy, fascism, and Marxism, neoliberalism is a term that some, but not all, scholars use to refer to a variety of concepts whose unifying characteristic is the free market. For the concept of free-market policies, critics prefer the term neoliberal, while proponents refer to "orthodox policies" or other synonyms invoking the mainstream nature of these reforms. To refer to the concept of a free-market paradigm, proponents use the term "neoclassical" instead of neoliberal. For the concept of a free-market ideology, those who espouse such views typically prefer the unqualified term "liberal." Finally, defenders of a free-market

Table 5 The four levels of contestation

\begin{tabular}{llll}
\hline & Democracy & Fascism & Marxism \\
\hline Contested term & No & No & No \\
Contested normative valence & No & No & Yes \\
Contested intension & Yes & Yes & Yes \\
Contested extension & Yes & Yes & Yes \\
\hline
\end{tabular}


development model in Pinochet's Chile referred to it as a "social market economy," though this term has since taken on different connotations. In each of the above cases, neoliberalism constitutes an example of what we call terminological contestation: scholars harbor divergent preferences for alternative terms to refer to a single underlying concept, and they express these preferences through the language of their own research.

While the normative valence of the term neoliberalism is clearly negative, each of the underlying concepts to which neoliberalism can refer has a contested normative valence. The contemporary examples of this pattern of terminological contestation are summarized in Table 6. Scholars harbor divergent normative opinions about freemarket ideology, policies, and paradigms, just as they do about the concept of Marxism. In the case of free-market concepts, preferences for alternative terminology divide along the same lines as opinions in this larger normative debate. Choosing words to refer to these concepts is not simply a neutral choice among equally attractive synonyms, because one's use of language invariably expresses a position as to whether free markets are good or bad.

As long as the term and normative valence of a concept are not both contested, scholars have a shared incentive in preventing it from being applied too broadly. Hence, we observe efforts to delimit the concept's range by contesting both intension and extension - arguing about which criteria should be included in its definition and which cases should qualify as examples. For example, maintaining democracy as a positively valued concept requires excluding marginal cases, lest the concept be sullied by its association with less-than-democratic regimes. Scholars face similar incentives when dealing with unambiguously negative concepts for which a common term exists. Fascism is generally regarded as a type of political regime that is even harsher than authoritarianism; this special significance would be diminished if the term were loosely defined and broadly applied. An incentive to delimit intension and extension remains even when normative valence is contested, as long as common language is employed. There are strong reasons to specify the meaning of Marxism, for instance, lest one's ideological opponents redefine the term to their advantage.

By contrast, in the case of neoliberalism, the conjunction of terminological contestation and the contested normative valence of the underlying concepts to which it can refer short circuits debate over the term's meaning and proper application. Because the normative valence of free market phenomena is contested, some scholars have an incentive to suggest that the negative aspects of markets are more widespread, whereas others have an incentive to argue that their positive aspects are more prevalent. Those who use neoliberalism, however, participate in

Table 6 Neoliberalism and terminological contestation

\begin{tabular}{lccc}
\hline $\begin{array}{l}\text { Concept: } \\
\text { Negative term: }\end{array}$ & $\begin{array}{c}\text { Free market policy } \\
\text { Neoliberal } \\
\text { Orthodox }\end{array}$ & $\begin{array}{c}\text { Free market ideology } \\
\text { Neoliberal } \\
\text { Liberal }\end{array}$ & $\begin{array}{c}\text { Free market paradigm } \\
\text { Neoliberal } \\
\text { Neoclassical }\end{array}$ \\
\hline Contested term & Yes & Yes & Yes \\
Contested normative valence & Yes & Yes & Yes \\
Contested intension & & BLOCKED & \\
Contested extension & & BLOCKED & \\
\hline
\end{tabular}


only one side of this debate. To contest the intension and extension of neoliberalism, by arguing that certain cases do not qualify or that certain definitional criteria do not belong, would be to suggest that the negative aspects of markets are not as widespread as others maintain - undercutting the still-unresolved argument about whether the free market is ultimately good or bad. The result is that neoliberalism has become a conceptual trash heap capable of accommodating multiple distasteful phenomena without much argument as to whether one or the other component really belongs. ${ }^{15}$

We are clearly concerned that the failure to use common terminology when discussing free markets circumvents meaningful academic debate, but we do not believe that the term neoliberalism need be discarded as a result. Other important social science terms, such as corporatism and totalitarianism, were once used much more pejoratively in academic research, but were transformed into useful analytic tools as a result of the deliberate efforts of scholars such as Philippe C. Schmitter (1974) and Juan Linz (2000 [1974]). We are hopeful that the present analysis contributes to a similar process in the case of neoliberalism. In the concluding section to this article, we sketch out some scenarios of how neoliberalism, shorn of its exclusively negative connotations and more widely adopted across ideological divides, might prove to be more useful in empirical research.

\section{Conclusion: Toward a 'New Liberalism' with Common Substantive Meaning}

The explosive use of neoliberalism in the social sciences presents an unusual challenge. As scholars, we are accustomed to addressing the problems associated with essentially contested concepts like democracy, and we have learned to justify our preferred definitions from among a range of alternatives. But academic use of neoliberalism is problematic in an entirely different way: its meaning is not debated, and it is often not defined at all. As a result, we are faced not with too many definitions but with too few. Neoliberalism is also used unevenly across ideological divides, rarely appearing in scholarship that is favorable toward free markets. To explain this peculiar scholarly usage, we have analyzed the historical circumstances that transformed neoliberalism from a positive term implying moderation to a negative term connoting radicalism. We then expanded upon Gallie's framework for analyzing essentially contested concepts by showing that there are multiple levels of contestation. Examining these distinct levels, we have argued that scholars fail to debate the intension and extension of neoliberalism because of the conjunction of terminological contestation and the contested normative valence of the underlying concepts to which the term can refer.

If neoliberalism is to be of analytic rather than rhetorical value to social scientists, it must regain a common substantive meaning, returning to its etymological roots and conveying the concrete notion of a "new liberalism." As we have demonstrated, neoliberalism was initially coined by the German Freiberg School for just this

\footnotetext{
15 There is evidence of scholars acting in just such a fashion and calling on others to do the same. According to Richard Hull (2006: 155), the work of Hilary Wainwright "argues that radical intellectuals should 'under-labour' to develop ideas, concepts, phrases and 'findings' that indirectly impact on progressive policy decisions."
} 
purpose: it denoted a form of liberalism that was specifically moderate in relation to classical liberalism because of its rejection of laissez-faire and emphasis on humanistic values. We do not advocate a return to this original definition; presentday usage of neoliberalism is clearly associated with radicalism, and changing this connotation would be neither easy nor necessarily desirable. Instead, the necessary task is to construct a specific and substantively rich definition of a new liberalism that builds upon this notion of radicalism where appropriate. For such a definition to take root in academic discourse, it will have to emerge out the sort of debate that is presently lacking. In place of proposing a definitive meaning for the term, we seek to initiate this debate by suggesting three distinct ways in which neoliberalism could once again be used to denote a "new liberalism" and distinguish between different forms of political economy.

A first potential application of the term neoliberalism is as a reference to the unique characteristics that distinguish modern capitalism from previous models of development. One of the most striking features of the contemporary era has been the waning or disappearance of alternatives to the free market. In the last quarter of the twentieth century, the world witnessed the outright collapse of import substitution industrialization in Latin America and state socialism in the former Eastern Bloc, as well as the severe decline of the developmental state model in East Asia and Keynesianism in Western Europe and North America. While some scholars see modern capitalism as a return to an earlier form of liberalism, there are multiple features of today's liberal models that set them apart from their predecessors, including production chains integrated across national borders, knowledge-based forms of property that challenge the enforcement of traditional property rights, and the emergence of large service sectors in the developed world and informal sectors in the developing world (Zysman and Newman 2006). Neoliberalism would seem a natural label for these new free-market models as scholars continue to explore the distinctions between present-day capitalist development and earlier forms of political economy.

A second potential application of the term neoliberalism would be to underscore how the expansion of free markets in the developing world has set these newer market systems apart from those of the advanced industrialized countries. Indeed, some of neoliberalism's radical connotations derive from the perception that economic reforms in the developing world during the past three decades represent an even more fundamentalist application of liberal recipes than in classic bastions of laissez-faire such as the United States and the United Kingdom. The privatization of pensions, beginning in Chile and spreading throughout Latin America and the postcommunist region, is a policy that liberals in the advanced industrial countries actively promote but have thus far failed to implement (Weyland 2005; Orenstein 2008). The flat tax, adopted in many Eastern European countries, is another example (Appel 2006). If scholars wish to distinguish between the radical forms of market economies emerging in the developing world and the traditional liberal market economies of North America and Western Europe, neoliberalism could prove a useful term for doing so.

Third, neoliberalism could be used to refer to a distinct type of market economy that includes countries from both the developed and developing worlds. In the study of advanced industrial economies, scholars have long sought to differentiate among different types of capitalism, according to national models (Shonfield 1960), patterns 
of interest representation (Schmitter and Lehmbruch 1979), systems of production and innovation (Johnson et al. 1989), and the presence or absence of institutions that facilitate coordination (Hall and Soskice 2001). These typologies, however, have rarely been extended beyond North America, Western Europe, and a few Asian countries. Therefore, instead of being used to emphasize distinctions between the developed and developing economies as a whole, neoliberalism might usefully denote a type of market economy found in both middle and upper-income countries that experienced periods of radical market reform, such as the United Kingdom during the Margaret Thatcher era, the United States under Ronald Reagan, and Chile during Pinochet's reign. Countries that experienced more gradual and less ideologically driven episodes of market reform, such as France and Mexico, could be classified as another type.

In conclusion, we wish to underscore that the problem with present-day use of neoliberalism is not that scholars hold normative opinions about the value of free markets, or even that they sometimes express these opinions in their empirical research. Normative concerns provide an important stimulus for conducting research that is relevant to real-world problems and sheds light on substantively important issues in new ways. Whether free markets are good or bad for society is one of the most important questions scholars can debate. Our contribution should be to bring facts and reasoned arguments to the table as opposed to politically charged language. We can begin to do this by transforming the term neoliberalism into one that conveys a common substantive meaning rather than a common ideological orientation, and is used by all parties to this debate.

Open Access This article is distributed under the terms of the Creative Commons Attribution Noncommercial License which permits any noncommercial use, distribution, and reproduction in any medium, provided the original author(s) and source are credited.

\section{Appendix: Article Sampling and Coding Procedure}

To select journal articles for content analysis, we conducted a search in September 2004 for "neoliberal* OR neo-liberal*" in the titles and abstracts of peer-reviewed academic journals in Proquest Research Library and EBSCO Business Source Premier. We ignored book reviews and articles where neoliberal was used only in the unrelated context of international relations or American politics. In an effort to select important and influential journals distributed among several subfields, and because the electronic search was somewhat unreliable for early years, we chose purposively from among the list of journals with more than five unique articles, selecting the three development, Latin American studies, and comparative politics journals that ranked highest on the "impact" criterion in Garand and Giles' (2003) survey.

In the journals that fell into our sample, we analyzed articles appearing between 1990 and 2004 to cover the period from the first sustained references to neoliberalism in the English-language academic literature (see Fig. 1) through the time our research began. To assemble the final sample, we double-checked the electronic search results, and for early years that were omitted from the electronic 
search, or where the article's printed abstract was not searched by the search engine, we did a manual search of titles and abstracts in print copies of the journals. Where articles included no abstracts, we examined the first two paragraphs. Finally, during the coding process, we eliminated a handful of articles in which the term neoliberalism appeared in the title or abstract but nowhere else in the article.

To assemble the database, we each read separately a group of about 10 articles, coded them, and then compared results. Where there were discrepancies, we discussed the results and came to agreement on a common coding decision. Coding was completed before developing hypotheses, so we believe that there was minimal inferential risk from conflating our roles as coders and analysts.

\section{References}

Aguirre Gamio H. Liquidación Histórica del APRA y del Colonialismo Neolibera. Lima: Ediciones Debate; 1962.

Allardyce G. What Fascism is Not: Thoughts on the Deflation of a Concept. Am Hist Rev. 1979;84 (2):367-8.

Aminzade R. From Race to Citizenship: The Indigenization Debate in Post-Socialist Tanzania. Stud Comp Int Dev. 2003;38(1):43-63.

Appel H. "International Imperatives and Tax Reform: Lessons from Postcommunist Europe. Comp Polit. 2006;39(1):43-62.

Berger P et al. "Cultura y Desarrollo Económico." Estudios Públicos 1990;40:31-66.

Boarman PM. Germany's Economic Dilemma: Inflation and the Balance of Payments. New Haven: Yale University Press; 1964.

Boeninger E. "Bases de un orden económico para la futura democracia en Chile." Estudios Públicos 1986;22:81-113.

Brohman J. Universalism, Eurocentrism, and Ideological Bias in Development Studies: From Modernisation to Neoliberalism. Third World Q. 1995;16(1):122-140.

Bullard N, Bello W, Malhotra K. Taming the tigers: the IMF and the Asian crisis. Third World Q. 1998;19 (3):505-556.

Burns AR. Review of Die Konkurrenz (Untersuchungen uber die Ordnungsprinzipien und Entwicklungstendenzen der Kapitalistischen Verkehrswirtschaft), by Georg Halm. J Polit Econ. 1930;38(4):490-491.

Carruthers D. Environmental Politics in Chile: Legacies of Dictatorship and Democracy. Third World Q. 2001;22(3):343-358.

Chirinos Soto E. Repercusión política de la inflación. PEC. 1964;80:3-4.

Chossudovsky M. The Neo-Liberal Model and the Mechanisms of Economic Repression: The Chilean Case. Co-existence. 1975;12:34-57.

Collier D, Mahon JE Jr. Conceptual 'Stretching' Revisited: Adapting Categories in Comparative Analysis. Am Polit Sci Rev. 1993;87(4):845-855.

Collier D, Levitsky S. Democracy with Adjectives: Conceptual Innovation in Comparative Research. World Polit. 1997;49:430-451.

Collier D, Levitsky S. "Democracy 'With Adjectives': Conceptual Innovation in Comparative Research." Working Paper 230, Helen Kellogg Institute for International Studies, University of Notre Dame. 1996.

Collier D, Hidalgo FD, Maciuceanu AO. Essentially Contested Concepts: Debates and Applications. J Polit Ideol. 2006;11(3):216-246.

Echeverría R et al. "Libertad y Coerción: Posiciones socialistas, posiciones liberales." Estudios Públicos 1985;19:91-112.

Ffrench-Davis R. El Experimento Monetarista en Chile: Una Síntesis Crítica. Desarrollo Econ. 1983;23 (90):163-196.

Flisfisch Á, Fontaine A. "El Espíritu del Capitalismo Democrático.” Estudios Públicos 1983;11:169-187.

Flisfisch Á. "Modelos Conceptuales de la Política." Estudios Públicos 1984;16:161-175.

Fontaine AA. Más allá del Leviatán: Hacia el resurgimiento de la libertad individual. Estudios Públicos. 1980;1:123-146.

Foxley A. Experimentos Neoliberales en América Latina. Colección Estudios CIEPLAN 7. 1982. 
Freeden M. Ideologies and Political Theory: A Conceptual Approach. New York: Oxford University Press; 1996.

Friedman M. "Liberalism, Old Style." Collier's Year Book. New York: P.F. Collier and Son; 1955. p. 360-363.

Friedman M. "Neo-liberalism and its Prospects." Milton Friedman Papers, Box 42, Folder 8, Hoover Institution Archives. 1951.

Friedman T. “A Manifesto For the Fast World.” New York Times Magazine (28 March). 1999.

Friedrich CJ. The Political Thought of Neo-Liberalism. The American Political Science Review. 1955;49 (2):509-525.

Gallie WB. Essentially Contested Concepts. Proceedings of the Aristotelian Society. 1956;56:167-198.

Gallo E. "Notas sobre el liberalismo clásico." Estudios Públicos 1986;21:243-257.

Garand JC, Giles MW. Journals in the Discipline: A Report on a New Survey of American Political Scientists. PS: Political Science \& Politics. 2003;36(2):293-308.

García Á. "Modelo Neoliberal y Desarrollo Nacional: Un Desencuentro.” Estudios Públicos 1983;11:75-90.

Gerber D. Constitutionalizing the Economy: German Neo-liberalism, Competition Law, and the 'New' Europe. American Journal of Comparative Law. 1994;42(1):25-84.

Gerring J. Social Science Methodology: A Criterial Framework. New York: Cambridge University Press; 2001.

Góngora M. Ensayo histórico sobre la noción de estado en Chile en los siglos XIX y XX. Santiago: Editorial Universitaria; 1986.

Hall PA, Soskice D, eds. 2001. Varieties of Capitalism: The Institutional Foundations of Comparative Advantage. New York: Oxford University Press.

Hanslowe KL. Neo-Liberalism: An Analysis and Proposed Application. Journal of Public Law. 1960;9 (1):96-114.

Hull R. "The great lie: Markets, freedom, and knowledge." In: Plehwe D, Walpen B, Neunhöffer G, editors. Neoliberal Hegemony: A Global Critique. New York: Routledge; 2006.

Irarrázaval I. "Promoción del Desarrollo Social Privado al Nivel Local: Una Propuesta." Estudios Públicos 1990;38:149-192.

Irisity J. Uruguay: El fracaso de la opción neo-liberal. Nueva Sociedad. 1975;21:17-37.

Johnson C, D’Andrea Tyson L, Zysman J, eds. 1989. Politics and Productivity. Cambridge, MA: Ballinger.

King L. Postcommunist Divergence: A Comparative Analysis of the Transition to Capitalism in Poland and Russia. Studies in Comparative International Development. 2002;37(3):3-34.

Kurtz MJ. Chile's Neoliberal Revolution: Incremental Decisions and Structural Transformation. Journal of Latin American Studies. 1999;31(2):399-427.

Labarca S. “'Historia Política y Parlamentaria (1891-1920)’ de Manuel Rivas Vicuña: 29 Años de Vida Republicana Evocados en 1.500 Páginas.” PEC. 1965;125:10-13.

Linz JJ. Totalitarian and Authoritarian Regimes. Boulder: Lynne Rienner; 2000. [1974].

Lynch N. Neopopulismo: un concepto vacío. Socialismo y Participación. 1999;86:63-80.

Medina E, Arreóla F. “Ludwig Von Mises: La Razón Pura en el Camino de la Libertad.” Estudios Públicos 1986;21:185-232.

Megay EN. Anti-Pluralist Liberalism: The German Neoliberals. Political Science Quarterly. 1970;85 (3):422-442.

Oliver HM. German Neoliberals. The Quarterly Journal of Economics. 1960;74(1):117-149.

Orenstein M. Privatizing Pensions: The Transnational Campaign for Social Security Reform. Princeton, NJ: Princeton University Press; 2008.

Peña Vial J. "Economía, Positivismo y Moral.” Estudios Públicos 1985;20:239-252.

Pollack M. The New Right in Chile, 1973-1997. New York: St. Martin's Press; 1999.

Ramos JR. Neoconservative economics in the southern cone of Latin America, 1973-1983. Baltimore: Johns Hopkins University Press; 1986.

Reitan E. Rape as an Essentially Contested Concept. Hypatia. 2001;16(2):43-66.

Riethof M. Labour Involvement in National and Regional Transformation Processes: The Case of Chile. Third World Quarterly. 1999;20(5):1049-1058.

Roberts KM. Neoliberalism and the Transformation of Populism in Latin America: The Peruvian Case. World Politics. 1995;48(1):82-116.

Röpke W. "Social-cristianismo y neo-liberalismo." PEC 1964;67: 6-8 and 68: 2-3, 6.

Ruiz JM. El Neoliberalismo en América Latina. In: Friedrich-Ebert-Stiftung, editor. Política Económica y Desarrollo de América Latina. Bonn-Bad Godesberg, Germany: Verlag Neue Gesellschaft GmbH; 1972.

Sang Ben M, Van Der Horst A. "Ideales de antaño, necesidades presentes: el liberalismo dominicano como filosofía emergente. In: Levine BB, editor. El Desafío Neoliberal: El Fin del Tercermundismo en América Latina. Bogotá, Colombia: Editorial Norma; 1992. 
Sartori G. Concept Misinformation in Comparative Politics. Am Polit Sci Rev. 1970;64:1033-53.

Sartori G. Guidelines for Concept Analysis. In: Sartori G, editor. Social Science Concepts: A Systematic Analysis. Beverly Hills: Sage Publications; 1984.

Schmitter PC. Still the Century of Corporatism? Rev Polit. 1974;36:85-131.

Schmitter PC, Lehmbruch Gerhard, editors. Trends toward Corporatist Intermediation. Beverly Hills: Sage Publications; 1979.

Seawright J, Collier D. Glossary. In: Brady HE, Collier D, editors. Rethinking Social Inquiry: Diverse Tools, Shared Standards. Lanham, MD: Rowman \& Littlefield; 2004.

Shonfield A. Modern Capitalism: The Changing Balance of Public and Private Power. New York: Oxford University Press; 1960.

Silva E. The State and Capital in Chile: Business Elites, Technocrats, and Market Economics. Boulder: Westview Press; 1996.

Skinner Q. Language and Social Change. In: Tully J, editor. Meaning and Context: Quentin Skinner and his Critics. Princeton: Princeton University Press; 1988.

Straus S. Contested Meanings and Conflicting Imperatives: A Conceptual Analysis of Genocide. J Genocide Res. 2001;3(3):349-375.

Tironi EB. “¿Por qué Chile necesita aranceles diferenciados?” Estudios Públicos 1985;19:21-36.

Valdés S. "Orígenes de la Crisis de la Deuda: ¿Nos Sobreendeudamos o Nos Prestaron en Exceso? Estudios Públicos 1989;33:135-174.

Valdés JG. Pinochet's Economists: The Chicago School of Economics in Chile. New York: Cambridge University Press; 1995.

Weyland K. Clarifying a Contested Concept: Populism in the Study of Latin American Politics. Comp Polit. 2001;34(1):1-22.

Weyland K. The Politics of Market Reform in Fragile Democracies: Argentina, Brazil, Peru, and Venezuela. Princeton: Princeton University Press; 2002.

Weyland K. Theories of Policy Diffusion: Lessons from Latin American Pension Reform. World Polit. 2005;57:262-295.

Williamson J. Our Agenda and the Washington Consensus. In: Kuczynski Pedro-Pablo, Williamson J, editors. After the Washington Consensus: Restarting Growth and Reform in Latin America. Washington, DC: Institute for International Economics; 2003.

Wilson B. When Social Democrats Choose Neoliberal Policies: The Case of Costa Rica. Comp Polit. 1994;26(2):149-168.

Zysman J, Newman A, editors. How Revolutionary was the Digital Revolution? National Responses, Market Transitions, and Global Technology. Stanford: Stanford University Press; 2006.

Taylor C. Boas is a Ph.D. candidate in political science at the University of California, Berkeley. His dissertation examines changes in the strategies and techniques of presidential election campaigns in Latin America over the past several decades. His research has appeared in Journal of Theoretical Politics, Latin American Research Review, and Studies in Comparative International Development.

Jordan Gans-Morse is a Ph.D. candidate in political science at the University of California, Berkeley. His research focuses on various political economy issues in postcommunist and Latin American countries, including property rights, the politics of economic transition, and welfare state development. His work has appeared in Comparative Political Studies and Post-Soviet Affairs. 